\title{
Pricing Model of Reverse Mortgage in China
}

\author{
Yang Bai ${ }^{1}$, Bin Wan ${ }^{2}$, Yiyi Jiang ${ }^{3}$, Jie Yan ${ }^{4}$, Chonggao Liu ${ }^{2}$ \\ ${ }^{1}$ Graduate School of Business Administration, Ajou University, Suwon, South Korea \\ ${ }^{2}$ Guali Middle School, Ziyuan County, Guilin, China \\ ${ }^{3}$ Chuanshan College, University of South China, Hengyang, China \\ ${ }^{4}$ Meixi Middle School, Ziyuan County, Guilin, China
}

\section{Email address:}

b198716y@hotmail.com (Yang Bai),wanbinwanshen123@163.com (Bin Wan)

\section{To cite this article:}

Yang Bai, Bin Wan, Yiyi Jiang, Jie Yan, Chonggao Liu. Pricing Model of Reverse Mortgage in China. Science Journal of Applied Mathematics and Statistics. Vol. 5, No. 2, 2017, pp. 94-97. doi: 10.11648/j.sjams.20170502.15

Received: January 19, 2017; Accepted: February 17, 2017; Published: March 29, 2017

\begin{abstract}
With the increasing aging problem, house-for-pension program is attracting more and more people's attention in China. As an important financial tool, reverse mortgage has been developed quite well in a number of developed countries across the globe. Therefore, with reference to the developed countries, it could be convenient and effective way to learn these mature and valuable experiences to develop old-age care products and systems which accord with the situation of China. The key of the practice of reverse mortgage relies on its pricing. The article therefore emphasizes on the pricing of reverse mortgage to research and expound. This paper tries to use a hybrid model to make a relatively comprehensive introduction of the product mix, pricing principle and the risk control of housing reverse mortgage. The potential issues that may confront during the course are discussed for future implementation.
\end{abstract}

Keywords: Reverse Mortgage, Pricing Model, Endowment Insurance, Risk

\section{Introduction}

House-for-pension scheme originated from Netherlands. And it has been matured in America. House-for-pension scheme refers to the house owner achieving the purpose of endowment via the effective operation of the house. There are the forms of housing substitution, rental housing swap, and sale-leaseback. In America, the main implementation of house-for-pension is housing reverse mortgage [5].

Housing reverse mortgage loan refers to the olds give their mortgage to business operation institutions (bank or insurance bank), and the institutions will do the comprehensive evaluation for borrower's expected life span and the expected value of real estate, then the institution issues loan to borrower in the form of lump-sum or a lifetime annuity payment [4].

At present, there are mainly three types of housing reverse mortgage loan in the United States. The first one is HECM (home equity conversion mortgage), which is sold by financial institutions and the United States government providing guarantee. The second one is home keeper reverse mortgage loan, which is funded by the United States government and enterprise offer sales and guarantee. The third type of housing reverse mortgage loan is entirely provided by private institutions, which is the pure private reverse mortgage loan and financial freedom loan, there is no government guarantee [5]. These three sorts of reverse mortgage products met the demands of different aging people groups and improved the living condition of the old.

The situation of China's aging population is severe. According to the United Nations' prediction, 2005-2030 is the acceleration of Chinese aging period, and the population is expected to increase by 145 million, and the elderly population is expected to increase by 202 million. On one hand, China's aging process has the characteristics of "not rich but old first", currently the social endowment insurance is in a low level and part of the olds' income is low. On the other hand, China's elderly population average owned housing wealth exceeds the total population average wealth, thus the phenomenon of people rich in housing but poor in cash emerges. As a powerful complement of the existing pension means, housing reverse mortgage loan is an efficient 
path to increase the olds' income, ease the burden of endowment security and revitalize the existing real estate resources [1]. The exploration of housing reverse mortgage loan in our country has broken the ice in recent years, since 2005 the "Nanjing mode", "Beijing mode", "Shanghai mode" and "Hangzhou mode" have been in exploration, moreover, in September 2013 the State Council also issued "several opinions on speed up the development of pension services" to encourage house-for-pension scheme pilot. However, house-for-pension scheme in China is still in its infancy, and it is still rather immature. Drawing lessons from other countries is significant to promote the cause of house-forpension scheme in China [5].

In the process of exploration of this new endowment mode, carrying out the housing reverse mortgage loan business is good for promoting the innovation of China's financial products, enriching the financial theory in real estate, perfecting the credit system construction. On a microscopic scale, housing reverse mortgage loan business achieved the transfer of real estate value, makes the old people rich in housing but poor in cash can withdraw the residual value of the housing in advance before death, at the same time it provides a stable cash flow income. It becomes a powerful supplement of endowment pension, which will be helpful to improve the olds' life and ease the burden of family endowment. In terms of macro level, the implementation of reverse mortgage loan can also stimulate the market transactions of real estate, promote consumption, stimulate domestic demand and promote national economic growth. Therefore, the study of housing reverse mortgage loan has profound theoretical and practical significance [4].

To start with, this paper analyzed the implementation of the background of housing reverse mortgage business in China, introduced the current situation of this business both at home and abroad. Then we set up housing reverse mortgage loan based on double life insurance actuarial pricing model. In the end, we analyzed the risk of housing reverse mortgage loan and the barrier to implement in China. Hoping it can provide some idea or references for China to carry out the housing reverse mortgage loan.

\section{Pricing Model of Housing Reverse Mortgage Loan}

There were some classical models of housing reverse mortgage loan in foreign academia. One famous pricing model is the payment factor pricing model, proposed by Chinloy and Megbolugbe (1994). It is also the initial model of reverse mortgage loan and almost all subsequent pricing model of housing reverse mortgage loan is based on this model. It calculated the payment factors of housing reverse mortgage loan through taking factors of interest rate, real estate price volatility, the rate of inflation, and the fluctuation coefficient of the elderly mortality rate into consideration. Then let the payment factor multiple the real estate prices. Currently the HECM (home equity conversion mortgage) has just adopted the payment factor model in terms of product pricing.

When designing the pricing model of housing reverse mortgage loan, we must take the specific features of two groups into account. First, single life status and double life status directly affect the characteristic variable of reverse mortgage loan product pricing. Single life status refers to the case of a single borrower applies for reverse mortgage loan, that is, for the duration we only need to consider the single borrower's future life. Double life status of reverse mortgage loan refers to the case of husband and wife share the house and applies for reverse mortgage loan. For the duration of this type of reverse mortgage loan we must wait until the last person of a couple dies. The calculation of the probability of the death of the reverse mortgage loan borrowers based on the survival distribution rule of the independent individuals.

Second, whether there is right of redemption in the reverse mortgage loan contract or not? It can be divided into the right of redemption reverse mortgage and no right of redemption reverse mortgage. As to no right of redemption reverse mortgage, the borrower could not redeem housing mortgage right via the methods of paying off loan before housing owner's death, thus, the deadline of this kind of reverse mortgage loan is directly associated with the borrower's future life. However, with the right of redemption reverse mortgage, the borrower has the opportunity to redeem the housing mortgage right, hence, lenders will confront the borrowers' prepayment risk under this sort of reverse mortgage.

Given that the main function of housing reverse mortgage loan is endowment in China, let's assume that Chinese housing reverse mortgage loan adopt the methods of life annuity payment. Namely, the housing is collateral, and lending institutions issue fixed annuity payments to the borrower within the prescribed period of payment (yearly or monthly) until the borrower's death, then the loan term ends and the lending institutions take back the borrower's housing to repay the loan principal and interest.

In the light of the property of exponential distribution, we assume that life span follows exponential distribution, then under the improved single life status, the pricing model of no right of redemption life annuity payment reverse mortgage loan product as follows:

$$
L S=\sum_{t=0}^{\max } \operatorname{Age-x+1}\left[\frac{H E Q_{t} *(1-\alpha) *(1-\beta)^{t}}{\prod_{S=1}^{\omega}\left(1+r_{S}\right)}\right] * e^{-\lambda t{ }_{\mathrm{t}} \mathrm{P}_{\mathrm{x}}}
$$

where HEQ = home equity amount at the time the loan is taken out;

$\mathrm{r}_{\mathrm{s}}=$ floating expected future riskless rate of return;

${ }_{t} P_{x}=$ probability of survival $\mathrm{t}$ periods from age $\mathrm{x}$;

max Age = oldest possible survival age from life table;

$\alpha=$ ratio of trading cost;

$\beta=$ straight-line depreciation rate of house;

Here, the fluctuation of housing value is the key factor 
which influences the housing reverse mortgage loan pricing, reasonable assessment of the fluctuation of mortgage housing value is the key of carrying out this financial innovation business smoothly. This paper assumes that the real value of the real estate has the following recurrence relation:

$$
\mathrm{HEQ}_{\mathrm{t}+1}=\varphi_{\mathrm{t}+1} \mathrm{H}_{\mathrm{t}}+\varepsilon_{\mathrm{t}+1}
$$

where $\left\{\varepsilon_{\mathrm{t}}\right\}$ is White Gaussian Noise and $\left\{\mathrm{H}_{\mathrm{t}}\right\}$ is the real price of subject matter in t period.

Based on the OLS (Ordinary Least Square), we can obtain

$$
\varphi_{\mathrm{t}+1}^{\prime}=\frac{\sum \mathrm{H}_{\mathrm{t}} \mathrm{H}_{\mathrm{t}-1}}{\sum \mathrm{H}_{\mathrm{t}-1}^{2}}
$$

Thus

$$
\mathrm{HEQ}_{\mathrm{t}}=\varphi_{\mathrm{t}}^{\prime} \mathrm{H}_{\mathrm{t}-1}=\frac{\sum \mathrm{H}_{\mathrm{t}-1} \mathrm{H}_{\mathrm{t}-2}}{\sum \mathrm{H}_{\mathrm{t}-2}^{2}} \mathrm{H}_{\mathrm{t}-1}
$$

\subsection{Pricing Model of Reverse Mortgage for Double Life Status}

Reverse mortgage loan for double life status refers to the couple apply for reverse mortgage loan via their shared house.

The contract duration of this type of reverse mortgage loan is the death of the last person of a couple. The model is as follows:

$$
L S=\sum_{t=0}^{\max } \operatorname{Age}-x+1\left[\frac{H E Q_{t} *(1-\alpha) *(1-\beta)^{t}}{\prod_{s=1}^{\omega}\left(1+r_{s}\right)}\right] * e^{-\lambda t *{ }_{t} P_{x y}}
$$

for double life status,

$$
\begin{aligned}
& { }_{t} \mathrm{P}_{\mathrm{xy}}=\mathrm{P}[\max [\mathrm{T}(\mathrm{x}), \mathrm{T}(\mathrm{y})>t] \\
& \quad=1-\mathrm{P}[\max [\mathrm{T}(\mathrm{x}), \mathrm{T}(\mathrm{y})<t] \\
& \quad=1-\mathrm{P}[\mathrm{T}(\mathrm{x})<t] \mathrm{P}[\mathrm{T}(\mathrm{y})<t] \\
& ={ }_{\mathrm{t}} \mathrm{P}_{\mathrm{x}}+{ }_{\mathrm{t}} \mathrm{P}_{\mathrm{y}}-{ }_{\mathrm{t}} \mathrm{P}_{\mathrm{x}} \cdot{ }_{\mathrm{t}} \mathrm{P}_{\mathrm{y}}
\end{aligned}
$$

then

$$
L S=\sum_{t=0}^{\max } \operatorname{Age-x+1}\left[\frac{H E Q_{t} *(1-\alpha) *(1-\beta)^{t}}{\prod_{S=1}^{\omega}\left(1+r_{S}\right)}\right] * e^{-\lambda t}\left({ }_{t} P_{x}+{ }_{t} P_{y}-{ }_{t} P_{x} *{ }_{t} P_{y}\right)
$$

likewise

$$
\mathrm{HEQ}_{\mathrm{t}}=\varphi_{\mathrm{t}}^{\prime} \mathrm{H}_{\mathrm{t}-1}=\frac{\sum \mathrm{H}_{\mathrm{t}-1} \mathrm{H}_{\mathrm{t}-2}}{\sum \mathrm{H}_{\mathrm{t}-2}^{2}} \mathrm{H}_{\mathrm{t}-1}
$$

lump-sum payment under the pricing model of the right of redemption reverse mortgage

Under double life status, the length of maturity of reverse mortgage loan based on the death of the last person of a couple.

the forecasted value of housing price at time $t$

$$
\mathrm{HEQ}_{\mathrm{t}}=\widehat{\varphi} \mathrm{H}_{\mathrm{t}-1}=\frac{\sum \mathrm{H}_{\mathrm{t}-1} \mathrm{H}_{\mathrm{t}-2}}{\sum \mathrm{H}_{\mathrm{t}-2}^{2}} \mathrm{H}_{\mathrm{t}-1}
$$

the amount of initial fee need to pay at time $t$

$$
\alpha H E Q_{t}=\alpha \frac{\sum \mathrm{H}_{\mathrm{t}-1} \mathrm{H}_{\mathrm{t}-2}}{\sum \mathrm{H}_{\mathrm{t}-2}^{2}} \mathrm{H}_{\mathrm{t}-1}
$$

the early period of loan principal and interest need to pay off

$$
\mathrm{LS} * \prod_{\mathrm{s}=1}^{\omega}\left(1+\mathrm{r}_{\mathrm{s}}\right)
$$

Determining whether exercises the right of redemption:

If $\mathrm{LS}-\alpha \mathrm{HEQ}_{\mathrm{t}}-\mathrm{LS} * \prod_{\mathrm{s}=1}^{\omega}\left(1+\mathrm{r}_{\mathrm{s}}\right)>0, \quad$ borrower exercises the right of redemption; if $\mathrm{LS}-\alpha \mathrm{HEQ}_{\mathrm{t}}-\mathrm{LS} *$ $\prod_{s=1}^{\omega}\left(1+r_{s}\right)<0$, borrower does not exercise the right of redemption.

\subsection{The Risk of Reverse Mortgage Loan in China}

\section{1) Interest Rate}

In an increasing interest rate situation, investor based on a fixed rate generally has the advantage to reinvest into higher yielding financial products. However, it is not available for the fixed rate reverse mortgage lender as reverse mortgage will not offer any immediate cash flows to the lender. Although a floating rate reverse mortgage seems more attractive to the lenders considering interest rate, it is not risk-free.

2) Use Right of Land

As in China, the ownership and use right of land is detached. Residents have right to use land but not ownership. In addition, the use right of resident land will expire in 70 years. We do not know how the regulations will change when the use right expires but reverse mortgage does not expire.

3) Longevity Risk

If a borrower's life expectancy is greater than it is assumed, he or she will stay in the house with more time than expected. At the same time, the lender has to continue paying for the borrower. The loan may finally exceed the amount from selling the house and the lender has no responsibility to recover the difference. This is called longevity risk.

Apart from the above risk factors, we should take the situation of China into account while implement the housing reverse mortgage loan, such as the residents' consumption habits, traditional culture, financial management system, tax, land policy and other factors. In the time yet to come, for the 
housing reverse mortgage loan business, we must consider China's national conditions and carry out the localization design on the basis of comparative analysis. In terms of pricing model, the choice and the estimation of related parameters are critical.

\section{Conclusions and Recommendations}

Through above analysis and calculation we can draw these following conclusions:

On one hand, housing system reform and years of commercial housing sales have made housing become a major asset in the majority of Chinese urban households, which will lay a solid foundation for the promotion of housing reverse mortgage loan in China. On the other hand, the pace of China's rapidly aging society has brought unprecedented pressure for the social old-age security system, which makes the housing reverse mortgage loan become a supplement of the social pension system and an effective tool to reduce the pressure for public finance. Finally, years of family planning policy provides appropriate psychological basis and cultural soil for the housing reverse mortgage loan. Due to the family planning policy has weakened the heritage motivation and strengthened the pursuit of QOL (quality of life) in the old. Thereby, China's current economic and cultural environments are in favor of the initiation, generalization and development of the housing reverse mortgage loan.

As increasingly the financial world opening to the outside world, China's life insurance companies are facing intensive competition in the market. Such problems as the narrow investment channels, a lack of new product supply and weak product development ability are gradually exposed. Housing reverse mortgage loan is one of the means to improve the above exposed problems. If the analysis and conclusion in this paper can provide some idea for China to carry out the housing reverse mortgage loan, it would be a great success and the purpose of this paper is also attained.

\section{References}

[1] Ban Xiaona, Li Dongyang. Housing Reverse Mortgage Loan Endowment Patterns in the United States and Its Enlightenment. 2015.

[2] Chen Lei. On China's Pension Financial Innovation and the Pricing Model of Housing Reverse Mortgage. 2014.

[3] Jin Xiao-tong, Cui Hong-jing. Experience References from Asian Countries' "House-for-pension Scheme" - An Example of Reverse Mortgage in Japan and Singapore. 2014.

[4] Shen Hongbo, Wang Xuguo, Lu Yiliu. The Pricing Model and Rish Analysis of Reverse Housing Mortgage. 2013.

[5] Yu Yan-fang. Experience and Enlightenment from American Reverse Mortgage of House-for-pension Scheme. 2015.

[6] Zhao Li-xia. Combined Insurance Actuarial Model under Stochastic Interest Rate and Dependent Lifetime. Journal of Inner Mongolia Normal University (Natural Science Edition), 2014, Vol.43 No.4.

[7] Olivias. Mitchell, John. Piggott. Unlocking Housing Equity In Japan[J]. Journal of the Japanese and International Economies, 2004, 18(4):466-505.

[8] Ward SC, Chapman CB, Klein JH. Theoretical versus applied models: the newsboy problem. Omega 1991;19:197-206.

[9] Jaynes, E. T. 2003. Probability Theory: The Logic of Science. Cambridge University Press, Cambridge, UK.

[10] Suh-Ryung Kim, Jung Yeun Lee, Boram Park, and Yoshio Sano: The competition hypergraphs of doubly partial orders, Discrete Applied Mathematics, 165(2014) 185-191. 